\title{
Testing possible relationships between Acropora digitifera genes, seawater chemistry and skeletal elements
}

\author{
TOMOKo Bell, ${ }^{1,2 *}$ AKIRA IgUChI, ${ }^{3}$ ATSUSHI SUZUKI, ${ }^{4}$ ARISA SEKI ${ }^{2}$ and YUSUKe YoKOYAMA ${ }^{1,2}$ \\ ${ }^{1}$ Atmosphere and Ocean Research Institute, The University of Tokyo, \\ 5-1-5, Kashiwanoha, Kashiwa-shi, Chiba 277-8564, Japan \\ ${ }^{2}$ Department of Earth and Planetary Science, Graduate School of Science, The University of Tokyo, \\ 7-3-1, Hongo, Bunkyo-ku, Tokyo 113-0033, Japan \\ ${ }^{3}$ Department of Bioresources Engineering, National Institute of Technology, Okinawa College, \\ Henoko 905, Nago-shi, Okinawa 905-2192, Japan \\ ${ }^{4}$ Geological Survey of Japan, National Institute of Advanced Industrial Science and Technology, \\ 1-1-1, Higashi, Tsukuba, Ibaraki 305-8567, Japan
}

(Received December 9, 2016; Accepted December 1, 2017)

\begin{abstract}
Coral skeletons are robust tools for examining past environments. However, biogenic effects during skeletal formation cause uncertainties in paleoclimate reconstructions. Thus establishing a method to separate biogenic effects from abiogenic ones during skeletal formation is required. Here we utilized an open access and searchable gene database for the staghorn coral Acropora digitifera and examined the number of genes related to the elements in seawater to assess the origin of uncertainties in geochemical proxies. We found that $A$. digitifera has genes that can process at least 15 chemical elements as individual substances ( $\mathrm{Ca}, \mathrm{Na}, \mathrm{Zn}, \mathrm{K}, \mathrm{C}, \mathrm{N}, \mathrm{Cl}, \mathrm{S}, \mathrm{Fe}, \mathrm{Mg}, \mathrm{Mn}, \mathrm{Cu}, \mathrm{H}, \mathrm{Mo}$, and Te) and transporters for seven of these elements ( $\mathrm{Ca}, \mathrm{Na}, \mathrm{Zn}, \mathrm{K}, \mathrm{Cl}, \mathrm{Cu}$, and $\mathrm{H}$ ). The number of Ca-related genes was the highest (at least 428 genes, including 53 transporters), whereas $\mathrm{Sr}$, one of the most widely used geochemical proxies, was not found in the gene database. Furthermore, we analyzed skeletal samples of $A$. digitifera exhibiting different growth rates; their $\mathrm{Sr} / \mathrm{Ca}$ ratios showed the lowest variation $(1.9 \%)$, whereas other proxies $(\mathrm{K} / \mathrm{Ca}, \mathrm{Na} / \mathrm{Ca}$, and $\mathrm{Mg} / \mathrm{Ca}$ ) showed higher variation $(2.3-11.9 \%)$. This might be linked to the number of genes related to the proxies (namely, the magnitude of biogenic and/or abiogenic effects). We suggest that considering elements with no relevant coral genes could provide effective criteria for reliable proxies (e.g., $\mathrm{Sr} / \mathrm{Ca}, \mathrm{Li} / \mathrm{Ca}$ and $\mathrm{U} / \mathrm{Ca})$.
\end{abstract}

Keywords: seawater element, geochemical proxies, genomic information, scleractinian coral, Acropora digitifera

\section{INTRODUCTION}

Scleractinian corals (including the staghorn corals) form massive amounts of calcium carbonate $\left(\mathrm{CaCO}_{3}\right)$, and their calcification rate is estimated to be $2-6 \mathrm{~kg} \mathrm{CaCO}_{3}$ $\mathrm{m}^{-2} \mathrm{yr}^{-1}$ (Barnes and Devereux, 1984). Coral reefs cover an area of over $284,300 \mathrm{~km}^{2}$ globally (Spalding et al., 2001 ), which is $\sim 0.08 \%$ of the entire ocean surface. Given that ocean environments (e.g., seawater elements and physical conditions such as temperature) influence the composition and concentration of elements in coral skeletons, they have been used as effective geochemical tools to investigate past environments (e.g., Yokoyama and Esat, 2015; Yokoyama et al., 2011). For example, $\mathrm{Sr} / \mathrm{Ca}$

\footnotetext{
*Corresponding author (e-mail: tbell@aori.u-tokyo.ac.jp)

Copyright (C) 2018 by The Geochemical Society of Japan.
}

ratios in coral skeletons have been widely used to reconstruct sea surface temperature (SST) (e.g., Gagan et al., 2000; Seki et al., 2012; Felis et al., 2014), and the calcium accumulation in coral skeletons has been explained as mainly inorganic precipitation (Kinsman and Holland, 1969; Dietzel et al., 2004). Also, a variety of chemical ratios (e.g., $\mathrm{U} / \mathrm{Ca}, \mathrm{Li} / \mathrm{Mg}$, and $\mathrm{Cd} / \mathrm{Ca}$ ), have been applied as geochemical proxies (e.g., Inoue et al., 2011; Montagna et al., 2014; Pretet et al., 2014). One downside to using coral skeletons as geochemical proxies is the potential uncertainties related to biomineralization processes (e.g., biogenic effects) such as growth-rate-related kinetic effects (e.g., Hayashi et al., 2013; Hirabayashi et al., 2013) and individual variability (e.g., Bell et al., 2017). If the magnitude of these effects during skeletal formation is high, coral skeletons cannot be considered robust tools for reconstructing past environments. However, the mechanisms causing these uncertainties in coral skeletal proxies remain unclear. For example, $\mathrm{Mg} / \mathrm{Ca}$ ratios have 
been well studied as SST proxies, but most of the studies reported lower correlations between $\mathrm{SST}$ and $\mathrm{Sr} / \mathrm{Ca}$ ratios (e.g., Inoue et al., 2007). To elucidate this phenomenon, Wang and $\mathrm{Xu}$ (2001) suggested an energy partition model to explain the difference between $\mathrm{Sr}$ and $\mathrm{Mg}$. They calculated that the distribution coefficients of $\mathrm{Sr}, \mathrm{Mg}$, and Ca were 1.26, 0.0087, and 1, respectively, in aragonite. They suggested that $\mathrm{Sr}$ has stronger ability to bind to $\mathrm{Ca}$ abiogenically than $\mathrm{Mg}$ does. Gene composition from genome information, as related to specific elements, could help us understand this aspect. Nevertheless, there are no systematic explanations by which to evaluate the biogenic effects observed in geochemical proxies.

Owing to recent progress in providing coral genome information through increased throughput of next-generation sequencing technologies (Meyer et al., 2009; Shinzato et al., 2011), molecular-based research on biological processes of corals has also advanced rapidly (e.g., biomineralization; Moya et al., 2012; Vidal-Dupiol et al., 2013). Several molecules have been proposed to form the molecular basis of coral calcification (e.g., $\mathrm{Ca}^{2+}$ ATPase (Zoccola et al., 2004), carbonic anhydrase (Moya et al., 2008), and organic matrix protein (Watanabe et al., 2003), yet the molecules related to seawater elements (except for $\mathrm{Ca}$ ) have not been fully explored. The entire genome sequence of $A$. digitifera, one of the dominant species in the coral reefs of Japan, has been decoded (Shinzato et al., 2011) and data on the gene components of the species are also available (Dunlap et al., 2013). Thus, this species is an ideal model for studying and understanding the molecular basis of coral calcification.

In this study, to elucidate the factors causing uncertainties in skeletal proxies, we searched for genes related to elemental metabolism using the genomic information of $A$. digitifera. We pursued the possibility that the existence of these genes could be used to distinguish biological influences on the formation of coral skeletons. Thus, we attempted to identify molecules specialized for metabolizing individual elements because this database allows us to search proteins by inputting elemental terms. For ions in seawater to be moved into coral bodies biogenically, corals need to have specific genes to transport them. Therefore, we hypothesized that the number and type of genes related to each element would be correlated with the magnitude of the relevant biological functions, and this might contribute to uncertainties on skeletal proxies affected by biological processes. In addition, we analyzed skeletal samples of $A$. digitifera exhibiting a wide range of growth rates in a common garden culture experiment (described below) to confirm the elemental variation in skeletal proxies. To our knowledge, this is the first study to combine studies of coral genomes and geochemistry to elucidate the robustness of geochemical proxies.

\section{Materials AND Methods}

Inventory of metabolic and transporter genes for seawater elements

To identify the genes in the coral genome related to metabolizing seawater elements, we used published data from ZoophyteBase (Dunlap et al., 2013). This allowed us to search for genes of $A$. digitifera that were predicted to produce the functional proteins that perform metabolic processes involving seawater elements. In ZoophyteBase, proteins of $A$. digitifera are annotated using hidden Markov models and the Kyoto Encyclopedia of Genes and Genomes (KEGG). The latter is widely used as a resource for investigating biological systems (Dunlap et al., 2013) and for linking genes to higher-level functions. With this search engine, we used chemical elements found in seawater as keywords to search for functional proteins related to each element. Although not all of the elements in the periodic table are present in seawater, we chose to investigate every element experimentally. In general, the simple substances in coral skeletons are analyzed as temperature proxies, and chemical compounds are not used. Therefore, it should be noted that chemical compounds, such as bicarbonate, were not investigated in our analysis although bicarbonate transporters in coral (Acropora millepora) have been studied (Moya et al., 2012). When a gene was found to have multiple local sequences expressing different functional proteins, that gene was counted based on the number of functional proteins. For example, the gene adi_v1.09241 appeared three times when the search for "calcium" was conducted because this gene consisted of three partial amino acid sequences that could express three different functional proteins. In this case, adi_v1.09241 was counted as three genes in this study. In addition, the number of transporters was counted for each element from ZoophyteBase. This is because transporters are known to regulate ion flows in various types of eukaryotic cell membranes and might have a functional role in calcification. Transporters control the movement of ions across cell membranes by binding to target ions, and if present in calicoblastic cell membranes, they control ion flows to extracytoplasmic calcifying fluid (ECF), where calcification occurs. According to Lodish et al. (2000), transporters can carry $\sim 10^{4}$ ions per second; thus, the inventory of transporter genes is informative for estimating the range and potentially the amount of ion transport from seawater to ECF.

\section{ICP-AES analysis of coral skeletons}

Several colonies of $A$. digitifera were selected from a fringing reef of Sesoko Island (Okinawa, Japan) in 2012. The branches of $A$. digitifera collected from these colonies were at least $3 \mathrm{~m}$ apart. All the samples were collected in strict accordance with good animal practice de- 
fined by the relevant national and/or local animal welfare bodies, and the sampling was performed with permission from the Japanese Municipality of Okinawa Prefecture. The branches from these colonies were attached to plastic bolts for the rearing experiment and cultured for around 12 months in an aquarium outside the Sesoko Station, Tropical Biosphere Research Center (University of the Ryukyus, Japan). The rearing experiment was performed under the same conditions as previous experiments using other coral species (Hayashi et al., 2013). From these experimental colonies, 13 branches from five different colonies were used for the following experiments. The coral skeletal weight was measured using the buoyant weight technique (Davies, 1989). The increase rate was calculated as the percentage change in skeletal weight relative to the initial weight per day during the experiment. In this study, we defined this percentage as the coral growth rate. The sections of the branches that grew over the plastic bolts, the area of growth during the 12 month rearing experiment, were clipped and soaked in $30 \% \mathrm{H}_{2} \mathrm{O}_{2}$ for seven days to dissolve organic matter. Then, the fragment samples were washed with $18.2 \Omega$ ultrapure water in an ultrasonic bath for 10 minutes, and this washing process was repeated five times. Afterwards, the fragment samples were dried at $45^{\circ} \mathrm{C}$ in an oven overnight. Tenmilligram powdered samples were prepared and dissolved with $5 \% \mathrm{HNO}_{3}$ (Tamapure AA, Tama Chemicals) for the analysis. We measured the concentrations of five elements ( $\mathrm{Sr}, \mathrm{Ca}, \mathrm{Mg}, \mathrm{K}$, and $\mathrm{Na}$ ) for all 13 samples using inductively coupled plasma-atomic emission spectrometry (iCAP6300 Duo, Thermo Fisher Scientific) and employed two types of standards: XSTC-13 (multi-element standard solution, SPEX) and JCp-1 (a coral standard material, Geological Survey of Japan) (Okai et al., 2002). These five elements were chosen because $\mathrm{Sr}, \mathrm{Ca}$, and $\mathrm{Mg}$ are commonly studied geochemical proxies, and because $\mathrm{Na}, \mathrm{K}$, and $\mathrm{Ca}$ were the elements with the highest number of transporter genes.

\section{Statistical analyses}

To examine the correlations between the variables, a Pearson's product-moment correlation test was performed. The differences in the variables (growth rate and skeletal element ratio) between colonies were tested using oneway analysis of variance (ANOVA). These analyses were conducted using R software (R Development Core Team, 2013).

\section{RESULTS AND DISCUSSION}

\section{Metabolic genes and seawater chemistry}

The numbers of metabolic genes for seawater elements were summarized using the periodic table (Table 1). The number of genes for each element was highly variable

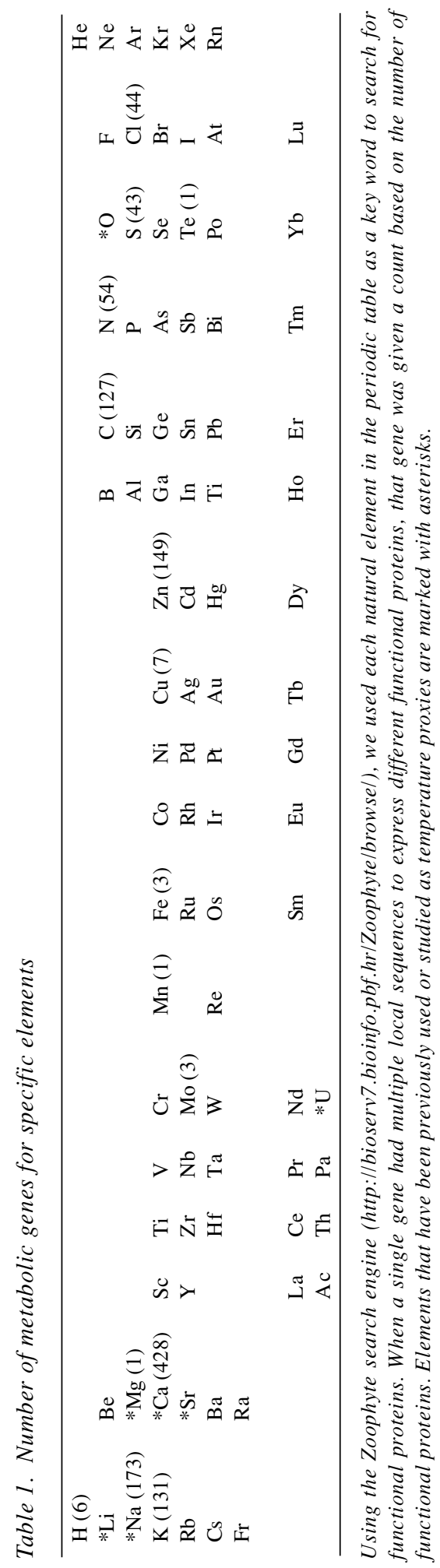

Coral genes, seawater chemistry and skeletal elements 
Table 2. Number of metabolic and transporter genes

\begin{tabular}{lcc}
\hline Chemical element & Number of metabolic genes & Number of transporters \\
\hline $\mathrm{Ca}$ & 428 & 53 \\
$\mathrm{Na}$ & 173 & 76 \\
$\mathrm{Zn}$ & 149 & 20 \\
$\mathrm{~K}$ & 131 & 39 \\
$\mathrm{C}$ & 127 & 0 \\
$\mathrm{~N}$ & 54 & 0 \\
$\mathrm{Cl}$ & 44 & 24 \\
$\mathrm{~S}$ & 43 & 0 \\
$\mathrm{Cu}$ & 7 & 4 \\
$\mathrm{H}$ & 6 & 6 \\
$\mathrm{Fe}$ & 3 & 0 \\
$\mathrm{Mo}$ & 3 & 0 \\
$\mathrm{Mg}$ & 1 & 0 \\
$\mathrm{Mn}$ & 1 & 0 \\
$\mathrm{Te}$ & 1 & 0 \\
\hline
\end{tabular}

(from 0 to 428 hits), and the chemical elements were aligned in order according to these numbers (Table 2). Because we were interested in these elements as geochemical tools, the elements that have been previously used as temperature proxies are marked with asterisks in Table 1 . There are 90 elements that occur in nature, and 15 of these had hits in the ZoophyteBase search $(\mathrm{Ca}, \mathrm{Na}$, $\mathrm{Zn}, \mathrm{K}, \mathrm{C}, \mathrm{N}, \mathrm{Cl}, \mathrm{S}, \mathrm{Fe}, \mathrm{Mg}, \mathrm{Mn}, \mathrm{Cu}, \mathrm{H}, \mathrm{Mo}$, and $\mathrm{Te}$ ). Therefore, A. digitifera has metabolic genes to process at least these 15 seawater elements as simple substances. Among the 15 seawater elements that could be processed by the metabolic genes of $A$. digitifera, five elements were major seawater elements whose concentrations are $>1 \mathrm{ppm}$ in seawater $(\mathrm{Cl}, \mathrm{Na}, \mathrm{Mg}, \mathrm{Ca}$, and $\mathrm{K})$, and seven elements ( $\mathrm{Zn}, \mathrm{S}, \mathrm{Fe}, \mathrm{Mn}, \mathrm{Cu}, \mathrm{Mo}$, and Te) were trace elements that are defined as those with concentrations of $<1 \mathrm{ppm}$. According to Pilson (1998), there are eight major elements in seawater that occur as simple substances: $\mathrm{Cl}(545.120$ $\mathrm{mmol} / \mathrm{kg}), \mathrm{Na}(469.00 \mathrm{mmol} / \mathrm{kg}), \mathrm{Mg}(52.82 \mathrm{mmol} / \mathrm{kg})$, $\mathrm{Ca}(10.27 \mathrm{mmol} / \mathrm{kg}), \mathrm{K}(10.21121 \mathrm{mmol} / \mathrm{kg}), \mathrm{Br}(0.842$ $\mathrm{mmol} / \mathrm{kg}), \mathrm{Sr}(0.090 \mathrm{mmol} / \mathrm{kg})$, and $\mathrm{F}(0.068 \mathrm{mmol} / \mathrm{kg})$. Of these eight major seawater elements, four were within the top 10 elements with the highest number of genes in Table 2: Ca (428 genes), Na (173), K (131), and Cl (44). Interestingly, genes related to three other major elements in seawater $(\mathrm{Sr}, \mathrm{Br}$, and $\mathrm{F}$ ) were not found in the ZoophyteBase search. Thus, it is possible that there are no specific metabolic genes to process these elements in spite of their high concentrations in seawater. It was noteworthy that $\mathrm{Sr}$, which is a major seawater element and the element most used as a geochemical proxy, was not found in the database. Although $\mathrm{Ca}$ had only the fourth highest concentration (411.9 ppm) among the five major seawater elements, the number of genes related to $\mathrm{Ca}$ was the highest (428 genes). Moreover, the number of Ca-related metabolic genes was more than two times greater than the number of genes for the second-ranking element, $\mathrm{Na}$ (173 genes).

The appearance of new genes and earth environments might be partly correlated. For example, the appearance of manganese catalase, which breaks down hydrogen peroxide into oxygen is tied to a major oxygenation event about 2.4 billion years ago (Kim et al., 2012). In this study, we compared the concentration of each element in seawater and the number of corresponding genes to see if we could find any correlations between the number of metabolic genes and the elemental concentrations in seawater (Fig. 1). No significant correlations were confirmed in the following three types of groups: (1) major and trace seawater elements together $(p=0.16, r=0.46)$, (2) only major elements ( $p=0.41, r=-0.48)$, and (3) only trace elements $(p=0.64, r=0.24)$. This indicates that, at least using our approach, the numbers of metabolic genes are not determined simply by the chemical composition and concentration of the elements in seawater. It should be noted that the numbers of genes related to each element are associated with not only coral calcification but also other metabolic processes. For example, calmodulin, which is one of the $\mathrm{Ca}^{2+}$-sensing proteins and was found in the coral genome (Dunlap et al., 2013), has many regulatory roles such as cytoskeleton organization, cellular metabolism, and cell differentiation (Benaim and Villalobo, 2002; Cyert, 2001; Vetter and Leclerc, 2003). Thus, calcium is involved in many metabolic processes in addition to skeletal formation in the corals mentioned above.

\section{Transporter genes and seawater chemistry}

Of the 15 elements that are related to the metabolic genes of A. digitifera, we found that seven elements had related transporters $(\mathrm{Na}, \mathrm{K}, \mathrm{Cl}, \mathrm{Zn}, \mathrm{Ca}, \mathrm{Cu}$, and $\mathrm{H}$; Table 2). Although we cannot identify where the transporters 


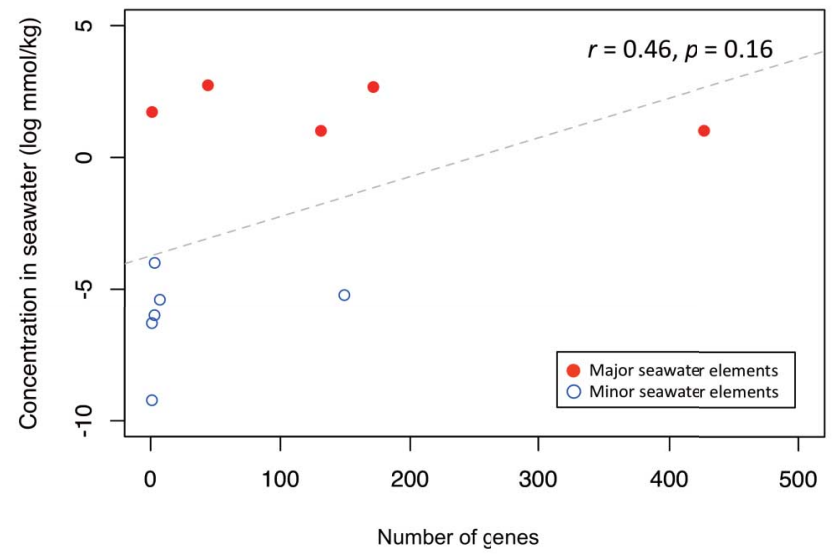

Fig. 1. Cross-plots of the number of genes and respective seawater concentrations of $\mathrm{Ca}, \mathrm{Na}, \mathrm{K}, \mathrm{Cl}$, and $\mathrm{Mg}$ (major seawater elements, red solid circles); and $\mathrm{Zn}, \mathrm{Mn}, \mathrm{Cu}, \mathrm{Fe}, \mathrm{Te}$, and Mo (minor seawater elements, blue circles). The seawater concentrations are from Pilson (1998).

are located, this finding suggests that at least these seven elements obtained from seawater are physically passed across membranes by transporters, possibly to reach the ECF of A. digitifera. In the ZoophyteBase search, the most relevant transporters were found for $\mathrm{Na}$ (76 transporters), $\mathrm{Ca}$ (53), and K (39). These three elements are all major seawater elements, and the transporters related to these elements may import or export these elements between cells and seawater. Interestingly, the trace elements $\mathrm{Zn}$ and $\mathrm{Cu}$, which are heavy metals known to have important biological roles (Morel and Price, 2003) as cofactors of many enzymes (Biscéré et al., 2015), were among the seven elements for which relevant transporters were found. We also searched for correlations between the numbers of transporter genes and mineral concentrations in seawater (Fig. 2). A significant correlation was confirmed in the first of the following three types of groups: (1) major and trace seawater elements $(p=0.02, r=0.68),(2)$ only major elements ( $p=0.87, r=0.10)$, and (3) only trace elements $(p=0.61, r=0.26)$. This indicates that the number of transporters could possibly be influenced by seawater chemistry; however, we need to collect more data from other taxa (e.g., other cnidarians) to confirm this trend.

\section{ICP-AES analysis of A. digitifera skeletons}

A total of 13 branches from five different colonies of A. digitifera showed different growth rates (0.23-1.61\%/ d) after the common-garden culture experiment (Fig. 3). The growth rates were significantly different among colonies $(\mathrm{F}(4,8)=23.898 ; p<0.001)$. Because it is a regular protocol in geochemical applications to normalize the skeletal element concentrations using the Ca concentra-

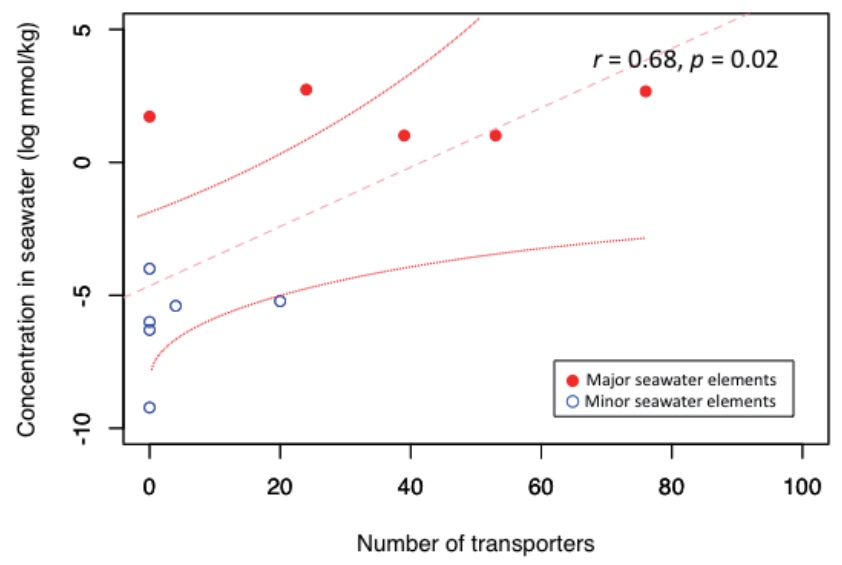

Fig. 2. Cross-plots of the number of transporters and respective seawater concentrations of $\mathrm{Ca}, \mathrm{Na}, \mathrm{K}, \mathrm{Cl}$, and $\mathrm{Mg}$ (major seawater elements, red solid circles); and $\mathrm{Zn}, \mathrm{Mn}, \mathrm{Cu}, \mathrm{Fe}, \mathrm{Te}$, and Mo (minor seawater elements, blue circles). Significant correlation was observed between the number of transporters and seawater concentration ( $p=0.02, r=0.68)$, and the pink dotted line represents the regression line: $y=0.112 x-4.646$. The red dotted lines represent the $95 \%$ confidence interval.

tion, we calculated $\mathrm{Sr} / \mathrm{Ca}, \mathrm{K} / \mathrm{Ca}, \mathrm{Na} / \mathrm{Ca}$, and $\mathrm{Mg} / \mathrm{Ca}$ for these 13 samples (Fig. 4). The $\mathrm{Sr} / \mathrm{Ca}, \mathrm{Na} / \mathrm{Ca}$, and $\mathrm{Mg} / \mathrm{Ca}$ values are within the ranges previously reported by Mitsuguchi et al. (2010), Gagan et al. (2000) and Inoue et al. (2007). Our K/Ca values (0.21-0.24 mmol/mol) are similar to those reported by Mitsuguchi and Kawakami (2012) for Porites sp. (0.16-0.22 $\mathrm{mmol} / \mathrm{mol})$. The values of these proxies were not significantly different among colonies $(\mathrm{F}(4,8)<3.69 ; p>0.05)$. However, intriguingly, the $\mathrm{Mg}$ values $(0.072-0.098 \mathrm{mmol})$ were significantly different among colonies $(\mathrm{F}(4,8)>5.4329 ; p<0.05)$ while those of $\mathrm{Sr}(0.14-0.18 \mathrm{mmol})$ were not $(\mathrm{F}(4,8)<0.2751$; $p>0.05)$. Thus, without standardization of calcium, magnesium showed colony-specific values. In geochemical studies, only one or two coral core samples are typically collected for skeletal-element analysis because geochemists are required to collect the most samples possible from one coral colony to obtain a few hundred years' worth of data. Thus, it is not feasible or realistic to collect more than three coral core samples. Therefore, to be a strong geochemical tool, a proxy based on coral skeletal elements should be consistent among colonies from the same environment, regardless of variations in growth rates. The standard deviations of $\mathrm{Sr} / \mathrm{Ca}, \mathrm{K} / \mathrm{Ca}, \mathrm{Na} / \mathrm{Ca}$, and $\mathrm{Mg} / \mathrm{Ca}$ were $(1.9,4.2,2.3$, and 11.9)\%, respectively. Thus, $\mathrm{Sr} / \mathrm{Ca}$ showed the smallest variation and $\mathrm{Mg} / \mathrm{Ca}$ showed the largest. Hayashi et al. (2013) also reported stable Sr/ Ca ratios among Porites australiensis samples with a fourfold growth-rate variation, which is a smaller range than found in this study (sevenfold variation). The wide range of $\mathrm{Mg} / \mathrm{Ca}$ ratios of Porites spp. has been reported in many 


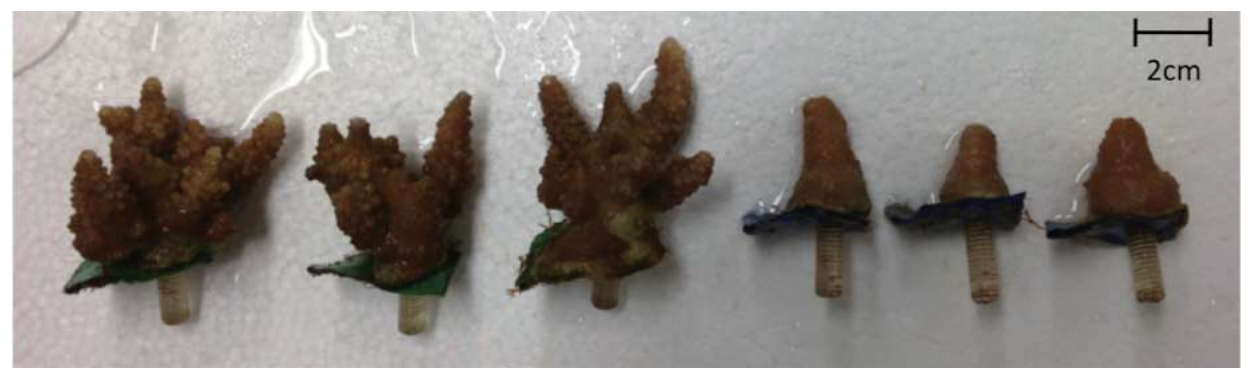

Fig. 3. Photo of six A. digitifera samples from two different colonies that showed the fastest and slowest growth rates $(0.23$ and $1.61 \% / d$, respectively) after 12 months in an outside aquarium at the Sesoko Station, Tropical Biosphere Research Center, University of the Ryukyus, Japan.
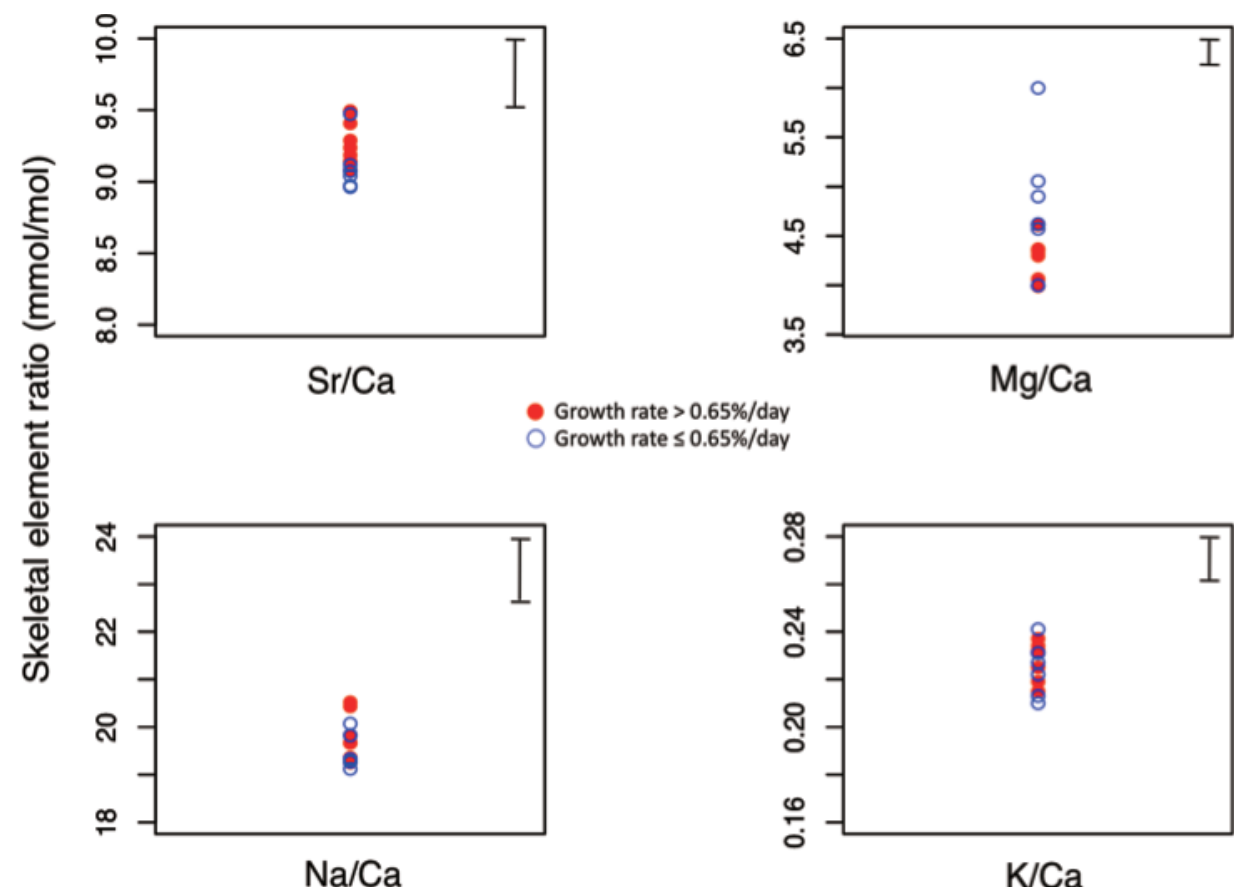

Growth rate $\leq 0.65 \% /$ day

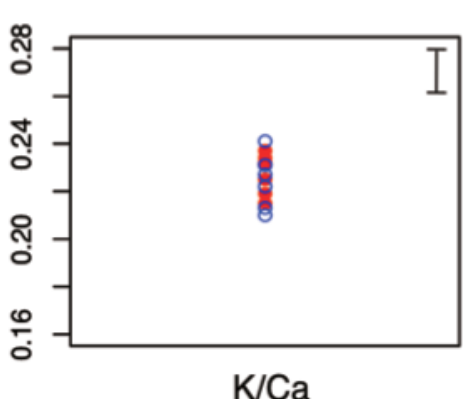

Fig. 4. Skeletal element ratios of 13 A. digitifera samples that showed varied growth rates (growth rate $>0.65 \% / d$ : red solid circles, growth rate $<0.65 \% / d$ : blue circles). The values of these proxies were not significantly different among colonies $(F(4,8)$ $<3.69$ ). The error bar indicates the maximum difference observed between two kinds of standards: XSTC-13 (multi-element standard solution, SPEX) and JCp-1 (a coral standard material, Geological Survey of Japan).

studies (e.g., Inoue et al., 2007), and their growth rates are considered to be related to the $\mathrm{Mg} / \mathrm{Ca}$ ratios in their skeletons. Therefore, we report the influence of growth rate on skeletal elements next.

\section{Influence of growth rate on skeletal elements}

The correlation between skeletal elements $(\mathrm{Sr} / \mathrm{Ca}, \mathrm{K} /$ $\mathrm{Ca}, \mathrm{Na} / \mathrm{Ca}$, and $\mathrm{Mg} / \mathrm{Ca}$ ) and growth rates were various and are summarized in Table 3. The correlation between growth rate and the $\mathrm{Mg} / \mathrm{Ca}$ ratio in this study was evident, as previously reported using Porites spp., and the correlation could be due to the difference in the partition coefficient between $\mathrm{Mg}$ and $\mathrm{Ca}$ in aragonite (Inoue et al., 2007). We also confirmed a significant correlation between growth rate and the $\mathrm{Sr} / \mathrm{Ca}$ ratio in A. digitifera. However, the correlation coefficients between skeletal elements and growth rates were $-0.69(p<0.01)$ and 0.24 $(p=0.42)$ for $\mathrm{Mg}$ and $\mathrm{Sr}$, respectively. Thus, $\mathrm{Mg}$ was correlated with the growth rate compared to $\mathrm{Sr}$, and one possible scenario was that $\mathrm{Mg}$ was acting as glue to cement molecules of $\mathrm{CaCO}_{3}$ (Bell et al., 2017). Interestingly, the variation in the $\mathrm{Sr} / \mathrm{Ca}$ ratio of $A$. digitifera was only $1.9 \%$, which was one-sixth of the variation in the $\mathrm{Mg} / \mathrm{Ca}$ ratio (11.9\%). Thus, the influence of the growth 
Table 3. Correlations between growth rates and skeletal elements

\begin{tabular}{lcccc}
\hline & $\mathrm{Sr} / \mathrm{Ca}$ & $\mathrm{Mg} / \mathrm{Ca}$ & $\mathrm{Na} / \mathrm{Ca}$ & $\mathrm{K} / \mathrm{Ca}$ \\
\hline Growth rate & $\mathbf{0 . 5 5}(\boldsymbol{p}=\mathbf{0 . 0 5})$ & $\mathbf{- 0 . 7 0}(\boldsymbol{p}=\mathbf{0 . 0 1})$ & $0.19(p=0.53)$ & $0.11(p=0.72)$ \\
$\mathrm{Sr} / \mathrm{Ca}$ & - & $-0.53(p=0.06)$ & $0.45(p=0.13)$ & $0.40(p=0.17)$ \\
$\mathrm{Mg} / \mathrm{Ca}$ & - & - & $-0.27(p=0.37)$ & $0.23(p=0.44)$ \\
$\mathrm{Na} / \mathrm{Ca}$ & - & - & - & $0.54(p=0.06)$ \\
$\mathrm{K} / \mathrm{Ca}$ & - & - & - & - \\
\hline
\end{tabular}

Significant correlations are written in bold letters.

rate on $\mathrm{Sr} / \mathrm{Ca}$ is much smaller than that on $\mathrm{Mg} / \mathrm{Ca}$ in $\mathrm{A}$. digitifera. Although there are no comparable studies investigating the relationship between growth rate and the $\mathrm{K} / \mathrm{Ca}$ or $\mathrm{Na} / \mathrm{Ca}$ ratio, our results show no correlations between these ratios and growth rate. It is noteworthy that Mitsuguchi and Kawakami (2012) reported a positive correlation between $\mathrm{K} / \mathrm{Ca}$ and $\mathrm{Na} / \mathrm{Ca}$, and our result also showed a positive correlation $(r=0.54, p=0.06$; Table $3)$. However, we need more data to compare our study to theirs because the number of our samples $(N=13)$ was many fewer than that of Mitsuguchi and Kawakami (2012) $(N=60)$.

\section{Relationships between the number of genes, growth rates} and skeletal elements

Our results using Zoophyebase showed that $A$. digitifera depends on at least 15 chemical elements in terms of genomic information. In general, the increase in the number of genes is related to biological complexity (Alberts et al., 2002). Moreover, Weng and Noel (2012) stated that metabolism is a complex network of chemical transformations mediated by a multitude of enzymes. Therefore, the number of genes can be an index of the complicity of metabolic processes. Considering the larger number of Ca-related genes in the coral genome, the implication is that a stable and well-developed $\mathrm{Ca}$ metabolic system exists in corals, and that $\mathrm{Ca}$ is metabolized in a regular and steady manner biogenically. However, we need to caution readers that the genes related to $\mathrm{Ca}$ are not always involved in the biogenic process of coral calcification (see the section, Metabolic Genes and Seawater Chemistry). Large numbers of genes related to $\mathrm{Na}$ and $\mathrm{K}$ exist, and they are also controlled biogenically by metabolic processes in A. digitifera. On the other hand, the chemical elements that exist in seawater but were not found in the gene database (e.g., $\mathrm{Sr}, \mathrm{Li}$, and $\mathrm{U}$ ) might be processed mainly abiogenically. The $\mathrm{Sr} / \mathrm{Ca}$ values had a variation of only $1.9 \%$, regardless of the growth rate of the coral colony, and the $\mathrm{Mg} / \mathrm{Ca}$ values showed the largest variation $(11.9 \%)$. We suggest that elements with no relevant coral genes could be good candidates for proxies with fewer biogenic effects (e.g., $\mathrm{Sr} / \mathrm{Ca}, \mathrm{Li} / \mathrm{Ca}$, and $\mathrm{U} / \mathrm{Ca}$ ). For example, $\mathrm{Li} / \mathrm{Ca}$ and $\mathrm{U} / \mathrm{Ca}$ were proposed as useful temperature proxies (e.g., Hathorne et al., 2013; Min et al., 1995); moreover, DeCarlo et al. (2016) recently introduced $\mathrm{Sr}-\mathrm{U}$ as a reliable temperature proxy by combining $\mathrm{Sr} / \mathrm{Ca}$ and $\mathrm{U} / \mathrm{Ca}$. Thus, the number of genes in coral genomes related to specific elements may provide at least partial criteria for determining reliable proxies.

At this stage, from the viewpoint of molecular physiology, it is unclear why the high correlation between $\mathrm{Mg}$ / $\mathrm{Ca}$ and growth rate was observed or why the variation in $\mathrm{Mg} / \mathrm{Ca}$ was the highest. Tanaka et al. (2015) conducted A. digitifera culture experiments at three different $\mathrm{pH}$ levels and reported that the variation of $\mathrm{Mg} / \mathrm{Ca}$ among $\mathrm{pH}$ conditions was statistically insignificant. Moreover, the variation of $\mathrm{Mg} / \mathrm{Ca}$ among three colonies was wider than that for two other colonies $(4.16-5.21 \mathrm{mmol} / \mathrm{mol})$. This implies strong biological control over skeletal $\mathrm{Mg} / \mathrm{Ca}$ during abiogenic fluctuations (e.g., $\mathrm{pH}$ ). They suggested that incorporation of $\mathrm{Mg} / \mathrm{Ca}$ is to some extent also affected by physiological, colony-specific factors. These uncertainties regarding $\mathrm{Mg} / \mathrm{Ca}$ could possibly be explained by our ongoing study focusing on $\mathrm{Mg}$-related gene expression among samples with different growth rates. Another intriguing finding in this study, the possible correlation between the number of transporters and specific elements in seawater should be investigated using other non-calcifying cnidarians such as Nematostella vectensis and Hydra magnipapillata, because their entire genome sequences are also available (Putnam et al., 2007; Chapman et al., 2010). On the other hand, it should be noted that results focusing on the number of genes need to be interpreted with some caution because there are some unknown genes in the coral genome (Shinzato et al., 2011) that might contribute to the elemental composition of coral skeletons. Thus, comprehensive gene expression profiling (such as RNA-seq) in the future, using coral branches with different growth rates, would provide more details on biogenic effects during skeletal formation. In addition, it is necessary to understand how ambient seawater is connected to calcification sites (ECF) in corals, namely, whether there are transcellular or paracellular pathways of skeletal materials to the ECF sites (e.g., Gagnon et al., 2012; Ohno et al., 2017). 


\section{Conclusions}

One of the most important topics in biomineralization research is whether chemical elements in marine calcifiers are controlled biogenically or abiogenically when they are transported from seawater into the skeleton. To resolve this issue, we propose that a bioinformatics approach using genome information would be an effective method. We suggest that elements with no relevant coral genes would make good candidates for reliable proxies. Genomic information can help us find new geochemical proxies with the fewest biogenic effects, and also explain the robustness of proxies that are already known to be effective in reconstructing past ocean environments.

Acknowledgments-The data used in this manuscript are available upon request to readers. This research was partly supported by the CANON Foundation (R12-Z-0013) and JSPS KAKENHI (26247085). We thank the Japanese Municipality of Okinawa Prefecture for the permit to collect the coral samples, and M. Inoue (Okayama University) and K. Kubota (The University of Tokyo) for their valuable advice on the ICP-AES analysis.

\section{REFERENCES}

Alberts, B., Johnson, A., Lewis, J., Raff, M., Roberts, H. and Walter, P. (2002) Molecular Biology of the Cell. 4th ed., Garland Science, Chap. 7.

Barnes, D. J. and Devereux, M. J. (1984) Productivity and calcification on a coral reef: a survey using $\mathrm{pH}$ and oxygen electrode techniques. J. Exp. Mar. Biol. Ecol. 9, 213-231.

Bell, T., Nishida, K., Ishikawa, K., Suzuki, A., Nakamura, T., Sakai, K., Iguchi, A. and Yokoyama, Y. (2017) Temperature controlled culture experiments using primary polyps of coral Acropora digitifera: their calcification rate variations and skeletal $\mathrm{Sr} / \mathrm{Ca}, \mathrm{Mg} / \mathrm{Ca}$, and $\mathrm{Na} / \mathrm{Ca}$ ratios. Paleogeogr. Paleoclimatol. Paleoecol. 484, 129-135.

Benaim, G. and Villalobo, A. (2002) Phosphorylation of calmodulin. Functional implications. Eur. J. Biochem. 269, 3619-3631.

Biscéré, T., Rodolfo-Metalpa, R., Lorrain, A., Chauvaud, L., Thébault, J., Clavier, J. and Houlbrèque, T. (2015) Responses of two Scleractinian corals to cobalt pollution and ocean acidification. PLOS ONE 10, e0122898, doi:10.1371/ journal.pone.0122898.

Chapman, J. A., Kirkness, E. F., Simakov, O., Hampson, S. E., Mitros, T., Weinmaier, T., Rattei, T., Balasubramanian, P. G., Borman, J., Busam, D., Disbennett, K., Pfannkoch, C., Sumin, N., Sutton, G. G., Viswanathan, L. D., Walenz, B., Goodstein, D. M., Hellsten, U., Kawashima, T., Prochnik, S. E., Putnam, N. H., Shu, S., Blumberg, B., Dana, C. E., Gee, L., Kibler, D. F., Law, L., Lindgens, D., Martinez, D. E., Peng, J., Wigge, P. A., Bertulat, B., Guder, C., Nakamura, Y., Ozbek, S., Watanabe, H., Khalturin, K., Hemmrich, G., Franke, A., Augustin, R., Fraune, S., Hayakawa, E., Hayakawa, S., Hirose, M., Hwang, J. S., Ikeo, K., Fujisawa, C. N., Ogura, A., Takahashi, T., Steinmetz, P. R. H., Zhang, X., Aufschnaiter, R., Eder, M. K., Gorny, A. K.,
Salvenmoser, W., Heimberg, A. M., Wheeler, B. M., Peterson, K. J., Bottger, A., Tischler, P., Wolf, A., Gojobori, T., Remington, K. A., Strausberg, R. L., Craig Venter, J., Technau, U., Hobmayer, B., Bosch, T. C. G., Holstein, T. W., Fujisawa, T., Bode, H. R., David, C. N., Rokhsar, D. S. and Steele, R. E. (2010) The dynamic genome of Hydra. Nature 464, 592-596.

Cyert, M. S. (2001) Genetic analysis of calmodulin and its targets in Saccharomyces cerevisiae. Annu. Rev. Genet. 35, 647-672.

Davies, P. S. (1989) Short-term growth measurements of corals using an accurate buoyant weighing technique. Mar. Biol. 101, 389-395.

DeCarlo, T. M., Gaetani, G. A., Cohen, A. L., Foster, G. L., Alpert, A. E. and Stewart, J. A. (2016) Coral Sr-U thermometry. Paleoceanography 31, 626-638.

Dietzel, M., Gussone, N. and Eisenhauer, A. (2004) Co-precipitation of $\mathrm{Sr}^{2+}$ and $\mathrm{Ba}^{2+}$ with aragonite by membrane diffusion of $\mathrm{CO}_{2}$ between 10 and $50^{\circ}$ C. Chem. Geol. 203, 139151.

Dunlap, W. C., Starcevic, A., Baranasic, D., Diminic, J., Zucko, J., Gacesa, R., van Oppen, M. J. H., Hranueli, D., Cullum, J. and Long, P. F. (2013) KEGG orthology-based annotation of the predicted proteome of Acropora digitifera: ZoophyteBase-an open access and searchable database of a coral genome. BMC Genomics 14, doi:10.1186/1471.

Felis, T., McGregor, H. V., Linsley, B. K., Tudhope, A. W., Gagan, M. K., Suzuki, A., Inoue, M., Thomas, A. L., Esat, T. M., Thompson, W. G., Tiwari, M., Potts, D. C., Mudelsee, M., Yokoyama, Y. and Webster, J. M. (2014) Intensification of the meridional temperature gradient in the Great Barrier Reef following the Last Glacial Maximum. Nat. Commun. 5, doi:10.1038/ncomms5102.

Gagan, M. K., Ayliffe, L. K., Beck, J. W., Cole, J. E., Druffel, E. R. M., Dunbar, R. B. and Schrag, D. P. (2000) New views of tropical paleoclimates from corals. Quat. Sci. Rev. 19, 45-64.

Gagnon, A. C., Adkins, J. F. and Erez, J. (2012) Seawater transport during coral biomineralization. Earth Planet. Sci. Lett. 329, 150-161.

Hathorne, E. C., Felis, T., Suzuki, A., Kawahata, H. and Cabioch, G. (2013) Lithium in the aragonite skeletons of massive Porites corals: A new tool to reconstruct tropical sea surface temperatures. Paleoceanography 28, 143-152.

Hayashi, E., Suzuki, A., Nakamura, T., Iwase, A., Ishimura, T., Iguchi, A., Sakai, K., Okai, T., Inoue, M., Araoka, D., Murayama, S. and Kawahata, H. (2013) Growth-rate influences on coral climate proxies tested by a multiple colony culture experiment. Earth Planet. Sci. Lett. 362, 198-206.

Hirabayashi, S., Yokoyama, Y., Suzuki, A., Kawakubo, Y., Miyairi, Y., Okai, T. and Nojima, S. (2013) Coral growthrate insensitive $\mathrm{Sr} / \mathrm{Ca}$ as a robust temperature recorder at the extreme latitudinal limits of Porites. Geochem. J. 47, e1-e5.

Inoue, M., Suzuki, A., Nohara, M., Hibino, K. and Kawahata, H. (2007) Empirical assessment of coral $\mathrm{Sr} / \mathrm{Ca}$ and $\mathrm{Mg} / \mathrm{Ca}$ ratios as climate proxies using colonies grown at different temperatures. Geophys. Res. Lett. 34, L12611.

Inoue, M., Suwa, R., Suzuki, A., Sakai, K. and Kawahata, H. 
(2011) Effects of seawater $\mathrm{pH}$ on growth and skeletal U/Ca ratios of Acropora digitifera coral polyps. Geophys. Res. Lett. 38, L12809, doi:10.1029/2011GL047786.

Kim, K. M., Qin, T., Jiang, Y. Y., Chen, L. L., Xiong, M., Caetano-Anollés, D., Zhang, H. Y. and Caetano-Anollés, G. (2012) Protein domain structure uncovers the origin of aerobic metabolism and the rise of planetary oxygen. Structure 20, 67-76.

Kinsman, D. J. J. and Holland, H. D. (1969) The co-precipitation of cations with $\mathrm{CaCO}_{3}-\mathrm{IV}$. The co-precipitation of $\mathrm{Sr}^{2+}$ with aragonite between 16 and $96^{\circ} \mathrm{C}$. Geochim. Cosmochim. Acta 33, 1-17.

Lodish, H., Berk, A., Zipursky, S. L., Matsudaira, P., Baltimore, D. and Darnell, J. (2000) Molecular Cell Biology. W. H. Freeman, Chap. 15.

Meyer, E., Aglyamova, G. V., Wang, S., Buchanan-Carter, J., Abrego, D., Colbourne, J. K., Willis, B. L. and Matz, M. V. (2009) Sequencing and de novo analysis of a coral larval transcriptome using 454 GSFlx. BMC Genomics 10 , doi:10.1186/1471-2164-10-219.

Min, G. R., Edwards, R. L., Taylor, F. W., Recy, J., Gallup, C. D. and Beck, J. W. (1995) Annual cycles of UCa in coral skeletons and UCa thermometry. Geochim. Cosmochim. Acta 59, 2025-2042.

Mitsuguchi, T. and Kawakami, T. (2012) Potassium and other minor elements in Porites corals: implications for skeletal geochemistry and paleoenvironmental reconstruction. Coral Reefs 31, 671-681.

Mitsuguchi, T., Uchida, T. and Matsumoto, E. (2010) Na/Ca variability in coral skeletons. Geochem. J. 44, 261-273.

Montagna, P., McCulloch, M., Douville, E., López Correa, M., Trotter, J., Rodolfo-Metalpa, R., Dissard, D., Ferrier-Pagès, C., Frank, N., Freiwald, A., Goldstein, S., Mazzoli, C., Reynaud, S., Rüggeberg, A., Russo, S. and Taviani, M. (2014) $\mathrm{Li} / \mathrm{Mg}$ systematics in scleractinian corals: Calibration of the thermometer. Geochim. Cosmochim. Acta 132, 288-310.

Morel, F. M. M. and Price, N. M. (2003) The biogeochemical cycles of trace metals in the Oceans. Science 300, 944-947.

Moya, A., Tambutté, S., Bertucci, A., Tambutté, E., Lotto, S., Vullo, D., Supuran, C. T., Allemand, D. and Zoccola, D. (2008) Carbonic anhydrase in the scleractinian coral Stylophora pistillata characterization, localization, and role in biomineralization. J. Biol. Chem. 283, 25475-25484.

Moya, A., Huisman, L., Ball, E. E., Hayward, D. C., Grasso, L. C., Chua, C., Woo, H. N., Gattuso, J. P., Foret, S. and Miller, D. J. (2012) Whole transcriptome analysis of the coral Acropora millepora reveals complex responses to $\mathrm{CO}_{2}-$ driven acidification during the initiation of calcification. Mol. Ecol. 21, 2440-2454.

Ohno, Y., Iguchi, A., Shinzato, C., Inoue, M., Suzuki, A., Sakai, K. and Nakamura, T. (2017) An aposymbiotic primary coral polyp counteracts acidification by active $\mathrm{pH}$ regulation. Sci. Rep. 7, 40324.

Okai, T., Suzuki, A., Kawahata, H., Terashima, S. and Imai, N. (2002) Preparation of a new Geological Survey of Japan geochemical reference material: Coral JCp-1. Geostand. Newsl. 26, 95-99.
Pilson, M. E. Q. (1998) An Introduction to the Chemistry of the Sea. Prentice Hall, Chap. 4.

Pretet, C., Reynaud, S., Ferrier-Pagès, C., Gattuso, J., Kamber, B. S. and Samankassou, E. (2014) Effect of salinity on the skeletal chemistry of cultured scleractinian zooxanthellate corals: $\mathrm{Cd} / \mathrm{Ca}$ ratio as a potential proxy for salinity reconstruction. Coral Reefs 33, 169-180.

Putnam, N. H., Srivastava, M., Hellsten, U., Dirks, B., Chapman, J., Salamov, A., Terry, A., Shapiro, H., Lindquist, E., Kapitonov, V. V., Jurka, J., Genikhovich, G., Grigoriev, I. V., Lucas, S. M., Steele, R. E., Finnerty, J. R., Technau, U., Martindale, M. Q. and Rokhsar, D. S. (2007) Sea anemone genome reveals ancestral eumetazoan gene repertoire and genomic organization. Science 317, 86-94.

R Development Core Team (2013) R: A language and environment for statistical computing. R Foundation for Statistical Computing, Vienna, Austria.

Seki, A., Yokoyama, Y., Suzuki, A., Kawakubo, Y., Okai, T., Miyairi, Y., Matsuzaki, H., Namizaki, N. and Kan, H. (2012) Mid-Holocene sea-surface temperature reconstruction using fossil corals from Kume Island, Ryukyus, Japan. Geochem. J. 46, e27-e32.

Shinzato, C., Eiichi, S., Kawashima, T., Hamada, M., Kanako, H., Makiko, T., Fujie, M., Fujiwara, M., Koyanagi, R., Ikuta, T., Fujiyama, A., Miller, D. J. and Satoh, N. (2011) Using the Acropora digitifera genome to understand coral responses to environmental change. Nature 476, 320-323.

Spalding, M. D., Ravilious, C. and Green, E. P. (2001). World Atlas of Coral Reefs. University of California Press, 10 pp.

Tanaka, K., Holcomb, M., Takahashi, A., Kurihara, H., Asami, R., Shinjo, R., Sowa, K., Rnkenburg, K., Watanabe, T. and McCulloch, M. (2015) Response of Acropora digitifera to ocean acidification: constraints from $\delta^{11} \mathrm{~B}, \mathrm{Sr}, \mathrm{Mg}$, and $\mathrm{Ba}$ compositions of aragonitic skeletons cultured under variable seawater pH. Coral Reefs 34, 1139-1149.

Vetter, S. W. and Leclerc, E. (2003) Novel aspects of calmodulin target recognition and activation. Eur. J. Biochem. 270, 404414.

Vidal-Dupiol, J., Zoccola, D., Tambutté, E., Grunau, C., Cosseau, C., Smith, K. M., Freitag, M., Dheilly, N. M., Allemand, D. and Tambutté, S. (2013) Genes related to iontransport and energy production are upregulated in response to $\mathrm{CO}_{2}$-Driven $\mathrm{pH}$ decrease in corals: new insights from transcriptome analysis. PLOS ONE 8, e58652.

Wang, Y. F. and Xu, H. F. (2001) Prediction of trace metal partitioning between minerals and aqueous solutions: A linear free energy correlation approach. Geochim. Cosmochim. Acta 65, 1529-1543.

Watanabe, T., Fukuda, I., China, K. and Isa, Y. (2003) Molecular analyses of protein components of the organic matrix in the exoskeleton of two scleractinian coral species. Comp. Biochem. Physiol. Part B: Biochem. Mol. Biol. 136, 767774.

Weng, J. K. and Noel, J. P. (2012) The remarkable pliability and promiscuity of specialized metabolism. Cold Spring Harbor Symp. Quant. Biol. 77, 309-320.

Yokoyama, Y. and Esat, T. (2015) Handbook of Sea-Level Research. John Wiley \& Sons, Chap. 7. 
Yokoyama, Y., Suzuki, A., Siringan, F., Maeda, Y., Abe-Ouchi, A., Ohgaito, R., Kawahata, H. and Matsuzaki, H. (2011) Mid-Holocene palaeoceanography of the northern South China Sea using coupled fossil-modern coral and atmosphere-ocean GCM model. Geophys. Res. Lett. 38, L00F03. Zoccola, D., Tambutté, E., Kulhanek, E., Puverel, S., Scimeca, J. C., Allemand, D. and Tambutté, S. (2004) Molecular cloning and localization of a PMCA P-type calcium ATPase from the coral Stylophora pistilla. Biochim. Biophys. Acta Biomembr. 1663, 117-126.

\section{SUPPlementARY MATERials}

URL (http://www.terrapub.co.jp/journals/GJ/archives/ data/52/MS511.pdf) 